\title{
In memory of parasitologist RNDr. Anna Gutteková, CSc.
}

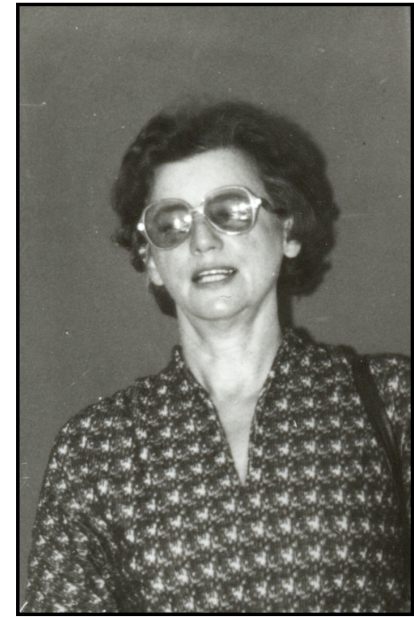

In November 2006 ten years will have passed since the departure of RNDr. Anna Gutteková, CSc., a significant research worker in the Helminthological (today Parasitological) Institute of the Slovak Akademy of Sciences (SAS) in Košice. On this occasion, the scientific community will commemorate her research achievements and rich publishing output.

Anna Gutteková was born on $28^{\text {th }}$ September 1928 in Bardejov to the family of Ján Guttek, a farmer (1900 - 1981) and Žofia, born Dzulíková (1900 - 1989), who was a housewife taking care of three children. Anna`s brother Ján had died shortly before the Second World War ended, before he reached 15 years of age, her sister Žofia, married Palčová, became a mining engineer.

In the years 1935 - 1940 Anna attended the elementary school in Bardejov, where she also studied at the state high school in 1941 - 1948. After she had passed her final exams, for a short time she worked as a teacher, in the years 1948 - 1949 in Košariská and in 1949 - 1950 at a secondary school in Bardejov. After that, in 1950 - 1954, she was an accountant in Narpa, a Košice - based company and in 1954 - 1955 in the District Construction Company (Okresný stavebný podnik) in Bardejov. In 1956 she started working in the County Hygienical and Epidemiological Station in Košice and decided to study at the Faculty of Natural Sciences Comenius University in Bratislava at the same time. She had finished her studies in 1964, after which she became a scientific worker of the Helminthological Institute of SAS in Košice, where she was working in the department of morphology and physiology until 1991. In 1992 she retired.

During her University studies she became dedicated to the research of adenoviruses, summarizing the outcome of this research in her thesis Adenoviruses and other hemadsorbing and hemaglutining viruses in removed tonsils and adenoid vegetation. The main object of her scientific re- search, however, was parasitology with the focus on helminthology. Especially in cooperation with doc. RNDr. I. Zmoray, DrSc., and later with RNDr. M. Bruňanská, CSc., she worked on an electron microscopical observation of the ultrastructure of the surface, muscle, intestinal and reproductive cells of parasitic as well as saprobiotic species of worms (Nematoda): Dictyocaulus filaria and D. viviparus, Müllerius capillaris, Eudorylaimus obtusicaudatus, Ascaridia galli, Cystocaulus ocreatus, Protostrongylus rufensus and P. commutatus, Haemonchus contortus, Heterakis gallinarum, Bunostonum trigonocephalum, Chabertia ovina, Nematodirus filicollis, Mammo-monogamus laryngeus, Thelazia gulosa and T. rhodesi, Amidostomum anseris, Proteocephalus longicollis and others. Electron microscopic observation of the cells' ultrastructure was a new method in Slovakia at times of beginning of Dr. Gutteková's scientific career and the ultra-structure of intestinal cells of various species of worms.

Dr. Gutteková defended her doctorate viva voce Ultrastructure of muscle cells of model nematoda in 1970 and in 1972 dissertation Comparative examination of the ultrastructure of muscles of model nematoda. In the Helminthological Institute of SAS she took part in carrying out governmental research tasks and she gave lectures on the outcomes of the research at specialist seminars and conferences home as well as abroad (1975 Bratislava, 1989 Prag, Berlin, České Budějovice). She authored and coauthored numerous scientific studies which she published in specialist magazines and journals Biológia, Bratislavské lekárske listy, Folia parasitologica, Folia veterinaria, Helminthologia, Veterinární medicína, Zeitschrift Parasitenkunde and others.

Along her scientific work, Dr. Gutteková also engaged in translating from English. In 1978, a large, 600 pages in length encyclopedia Svet živočíšnej ríše was published by Osveta in Martin, which she had translated from the English original, The Children`s Animal World Encyclopedia in Color (in 1990 a second edition was issued). She also translated various specialist commentaries for natural science films.

She engaged herself in some specialist societies, since 1959 she was a member of the Czechoslovak Red Cross, since 1964 Czechoslovak Parasitological Society at the CSAS and since 1965 Slovak Biological Society at SAS. RNDr. Anna Gutteková, CSc., died $16^{\text {th }}$ November 1996 in Košice at 68 years of age. Her almost 30-year-long scientific work has been liaised on by her younger co-workers who have started their careers in the Helminthological Institute of SAS under her leadership and who remember her with respect. 